DOI 10.15290/cnisk. 2018.01.05.02

MGR MARTA KUPCZEWSKA

orcid.org/0000-0002-7168-4927

Uniwersytet w Białymstoku

\title{
O roli kobiet w życiu publicznym XVII-wiecznej Rzeczypospolitej (w świetle korespondencji Katarzyny z Ostrogskich Zamoyskiej)
}

\section{Streszczenie}

Artykuł ma na celu przybliżenie publicznych aspektów działalności Katarzyny z Ostrogskich Zamoyskiej (około 1600-1642), żony drugiego ordynata Tomasza Zamoyskiego (1594-1638), w czasach panowania Zygmunta III i Władysława IV. Niniejsze dociekania w zamierzeniu maja uzupełnić dotychczasowe nieliczne badania odnoszace się do aktywności politycznej przedstawicielek elity magnackiej pierwszej połowy XVII w. oraz odpowiedzieć na pytanie o aktualność stereotypu związanego $z$ rzekomą obojętnościa kobiet baroku na sprawy polityczne i zawężeniem ich perspektyw do życia prywatnego (rodzinnego, religijnego lub, co najwyżej, gospodarczo-administracyjnego).

Słowa kluczowe: Katarzyna $z$ Ostrogskich Zamoyska, korespondencja, kobiety, działalność publiczna, XVII w. 


\title{
ON THE ROLE OF WOMEN IN THE PUBLIC LIFE OF THE 17TH- CENTURY POLISH-LITHUANIAN COMMONWEALTH (IN THE LIGHT OF KATARZYNA ZAMOYSKA NÉE OSTROGSKA'S CORRESPONDENCE)
}

\begin{abstract}
The article aims to bring closer the public activities of Katarzyna Zamoyska née Ostrogska (around 1600-1642), the wife of the second ordinate Tomasz Zamoyski (1594-1638), during the reign of Zygmunt III and Władysław IV. This inquiry intends to supplement the common research, currently limited to few studies concerning political activities of female representatives of the magnate elite of the first half of the 17th century and to answer the question regarding the current stereotypical view on the alleged indifference of Baroque women to political matters and narrowing their interests only to private life (i.e. family matters, religious observances or, at most, to magnates' estate managerial and administrative activities).

Keywords: Katarzyna Zamoyska née Ostrogska, correspondence, women, public activities, 17 th century

Badania nad szeroko rozumiana problematyka kobieca w historiografii polskiej prowadzone są na większą skalę już od ponad trzech dekad. Coraz liczniej powstaja prace poświęcone aktywności prywatnej, publicznej, gospodarczej oraz mecenatowi córek i żon magnatów ${ }^{1}$. Węższym nurtem w ramach badań nad kobietą w dawnych wiekach jest analiza ich prywatnej korespondencji. Szczególnym zainteresowaniem badaczy wykorzystujących źródła epistolarne cieszy się zwłaszcza okres od

\footnotetext{
1 Zob. m. in.: M. Bogucka, Białogłowa $w$ dawnej Polsce: kobieta $w$ społeczeństwie polskim XVI-XVIII wieku na tle porównawczym, Warszawa 1998 (tu znajduje się obszerna bibliografia prac zachodnioeuropejskich); Eadem, Kobieta w społeczeństwie polskim XVIXVII wieku [w:] Pamiętnik XV Powszechnego Zjazdu Historyków Polskich, t. 2: Przemiany społeczne a model rodziny, red. A. Żarnowska, Gdańsk-Torun 1995, s. 3-15; Ł. Charewiczowa, Kobieta $w$ dawnej Polsce: do okresu rozbiorów, Poznań 2002; Drogi kobiet do polityki (na przestrzeni XVIII-XXI wieku), red. T. Kulak, M. Dajnowicz, Wrocław 2006; Z. Kuchowicz, Postawa wobec kobiety $w$ kulturze szlacheckiej polskiego baroku [w:] Kobieta $w$ kulturze $i$ społeczeństwie, red. B. Jedynak, Lublin 1990, s. 7-50; Idem, Żywoty niepospolitych kobiet polskiego baroku, Łódź 1989; A. Wyrobisz, Kobiety w społeczeństwie staropolskim: wzorce a model rodziny [w:] Pamiętnik XV Powszechnego Zjazdu..., s. 17-22; Idem, Staropolskie wzory rodziny i kobiety - żony i matki, „Przegląd Historyczny” 1992, z. 3, s. 405-421.
} 
połowy XVII aż do schyłku XVIII w. ${ }^{2}$ Dotkliwie brakuje natomiast badań nad życiem prywatnym i publicznym magnatek żyjacych w XVI i pierwszej połowie XVII w. ${ }^{3}$ Niestety w dużej mierze spowodowane jest to szczatkowo zachowanymi źródłami odnoszącymi się do problematyki kobiecej.

Wydaje się, iż częściową próbę zapełnienia istniejącej luki związanej $z$ brakiem pogłębionych badań nad przejawami aktywności publicznej kobiet w czasach panowania dwóch pierwszych królów z dynastii Wazów można oprzeć na starannej analizie zachowanego głównie w Archiwum Zamoyskich, stosunkowo obszernego - jak na korespondencję kobieca z pierwszej połowy XVII w. - liczącego około 220 jednostek zbioru korespondencji Katarzyny z Ostrogskich Zamoyskiej (ur. około 1600 r. - zm. 6 października 1642 r.) $)^{4}$. Sa to listy z lat 1620-1642 skierowane nie tylko do jej męża Tomasza Zamoyskiego, lecz także do ważnych

2 Zob.: Kobiece kręi korespondencyjne w XVII-XIX wieku, red. B. Popiołek, U. Kicińska, A. Słaby, Warszawa 2016; Codzienne kłopoty, wielkie interesa i podwójna elekcja: korespondencja radziwiłłowskich urzędników z księżna Anna z Sanguszków Radziwiłłowa i jej synem Michałem Kazimierzem z 1733/ 1734 roku, wyd. J. Dygdała, Warszawa 2013; J. Rafałowiczówna, A z Warszawy nowiny te...: listy do Elżbiety Sieniawskiej z lat 1710-1720, oprac. B. Popiołek, Kraków 2000; B. Popiołek, Kobiecy świat w czasach Augusta II: studium z mentalności kobiecej czasów saskich, Kraków 2003 (tu rozbudowana bibliografia odnoszaca się do badań nad mentalnościa); Eadem, Królowa bez korony: studium z życia i działalności Elżbiety z Lubomirskich Sieniawskiej-ok. 1669-1729, Kraków 1996; Eadem, Dobrodziejki i klienci: $z$ dziejów patronatu kobiecego w czasach saskich [w:] Patron i dwór: magnateria Rzeczypospolitej w XVI-XVIII wieku, red. E. Dubas-Urwanowicz, J. Urwanowicz, Warszawa 2006, s. 385-395; A. Słaby, Dwór Elżbiety z Lubomirskich Sieniawskiej jako przykład patronatu kobiecego $w$ czasach saskich, Kraków 2014; W. Karkucińska, Anna z Sanguszków Radziwiłłowa (1676-1746): działalność gospodarcza i mecenat, Warszawa 2000; A. Jakuboszczak, Sarmacka dama: Barbara Sanguszkowa (1718-1791) i jej salon towarzyski, Poznań 2008; K. Targosz, Sawantki w Polsce XVII w.: aspiracje intelektualne kobiet ze środowisk dworskich, Warszawa 1997.

3 Do zupełnych wyjątków należą prace poświęcone aktywności publicznej magnatek w czasach panowania pierwszych Wazów. Jako jeden $z$ nielicznych zajął się nią ostatnio E. Opaliński, Aktywność kobiet $w$ życiu publicznym $w$ czasach pierwszych Wazów [w:] „Per mulierem...”: kobieta $w$ dawnej Polsce - w średniowieczu i w dobie staropolskiej, red. K. Justyniarska-Chojak, S. Konarska-Zimnicka, Warszawa 2010, s. 233-248. Zob. też: J. Partyka, „Żona wyćwiczona”: kobieta piszaca w kulturze XVI i XVII wieku, Warszawa 2004; P. Tyszka, W cieniu wielkiego kanclerza: Barbara z Tarnowskich Zamoyska, Warszawa 2015; S. Zagórska, Halszka z Ostroga: między faktami a mitami, Warszawa 2006; K. Górski, Matka Mortęska, Kraków 1971; J. Seredyka, Księżniczka i chudopachołek: Zofia z Radziwiłłów Drohostajska, Opole 1995.

4 Omawiana korespondencja znajduje się w Archiwum Głównym Akt Dawnych [AGAD], Archiwum Zamoyskich [AZ], 10, 412-424, 460, 924, 931-997. Dodatkowo kilkanaście listów Katarzyny Zamoyskiej w formie odpisów zachowało się także w innych archiwach: Biblioteka Narodowa [BN] Biblioteka Ordynacji Zamoyskich [BOZ], 1602; Biblioteka Raczyńskich, 80; Riksarkivet Stockholm [RS], Extranea IX Polen, 112. 
przedstawicieli ówczesnej sceny politycznej, takich jak m.in. wojewoda bełski Jakub Sobieski, hetman wielki koronny Stanisław Koniecpolski, biskup krakowski Marcin Szyszkowski, biskup kujawski Maciej Łubieński, biskup płocki Stanisław Łubieński czy biskup krakowski Jakub Zadzik. W zachowanej korespondencji znajdują się ponadto szczególnie wartościowe listy do i od poszczególnych członków rodziny królewskiej i jej najbliższego otoczenia. Druga ordynatowa zamojska korespondowała także z żonami i matkami, zarówno stronników politycznych Zamoyskiego, jak też osób ubiegających się o taki status. Utrzymywała przy tym kontakt ze swa liczną rodzina, przyjaciółkami (jak np. $z$ wojewodzina bełską Anną Leszczyńską czy marszałkową nadworną koronną Anną Opalińska), sąsiadami, wreszcie urzędnikami i dzierżawcami dóbr.

Katarzyna $z$ Ostrogskich Zamoyska była córką wojewody wołyńskiego księcia Aleksandra i Anny z Kostków ${ }^{5}$. W 1620 r., mając około dwudziestu lat, została żoną Tomasza Zamoyskiego, ówczesnego wojewody kijowskiego, a później podkanclerzego i wreszcie kanclerza wielkiego koronnego (ur. 1 kwietnia 1594 r. - zm. 8 stycznia 1638 r.) ${ }^{6}$. Plany powiazania domu Zamoyskich $z$ domem Ostrogskich jeszcze w ostatnich latach swojego życia snuł kanclerz i hetman wielki koronny Jan Zamoyski. Doskonale znał on bowiem znaczenie właściwie prowadzonej w społeczności szlacheckiej polityki matrymonialnej, będącej jednym ze środków budowania fortuny oraz korzystnego kształtowania kariery po-

\footnotetext{
5 Postacia Katarzyny Zamoyskiej nie interesowano się niemal zupełnie. Jedyny jak dotąd artykuł odnoszacy się do osoby drugiej ordynatowej zamojskiej zamieszczony został w ramach cyklu popularnonaukowego portretującego sylwetki kobiet $\mathrm{z}$ rodu Zamoyskich: A.L. Płatek, Kochajaca żona - Katarzyna z Ostrogskich Zamoyska (1600-1642), „Zamojski Kwartalnik Kulturalny" 2013, nr 2, s. 34-38. Listy Katarzyny Zamoyskiej do męża zanalizowane zostały przez A.A. Witusik, O Zamoyskich, Zamościu i Akademii Zamojskiej, Lublin 1978, s. 153-159. Analizy językowej korespondencji Katarzyny Zamoyskiej adresowanej do męża (37 listów z lat 1620-1632) dokonała H. Wiśniewska, Kultura języka Katarzyny Zamoyskiej w świetle jej listów do męża, „Pamiętnik Literacki” 1990, t. 81, z. 4, s. $169-172$.

6 Już 18 lutego 1620 r. w Jarosławiu podpisano - opiewająca na ponad 53333 zł posagu i tyleż oprawy - intercyzę ślubna, zaś 1 marca 1620 r. odbył się ślub, którego udzielał arcybiskup lwowski Jan Andrzej Próchnicki. Przenosiny panny młodej do Zamościa miały miejsce 17 maja 1620 r. (Biblioteka Ossolineum, 1904/II, Intercyza ślubna z Katarzyną księżniczką Ostrogską między księżną Imcią Anną z Szemberka Ostrogską wojewodzina wołyńską uczyniona a Imcią Panem Tomaszem Zamoyskim wojewodą kijowskim, k. 3333v, [druk: Intercyza ślubna z Katarzyna księżniczka Ostrogska między księżna Imcia Anna z Szemberka Ostrogska wojewodzina wołyńska uczyniona a Imcia Panem Tomaszem Zamoyskim wojewoda kijowskim, oprac. M. Kupczewska, „Białostockie Teki Historyczne” 2013, t. 11, s. 291-293]).
} 
litycznej i towarzyskiej ${ }^{7}$. O ile jednak jeszcze na początku XVII w. dom Ostrogskich zaliczał się do najznaczniejszych, a ich majątek ziemski był jednym $z$ największych w ówczesnej Rzeczypospolitej ${ }^{8}$, o tyle już na przełomie drugiego i trzeciego dziesięciolecia XVII w. sytuacja rodowa ksiażąt uległa diametralnej zmianie, a ród Ostrogskich - tracac kolejno swych męskich przedstawicieli - wymierał. Katarzyna jako jedna $z$ ostatnich przedstawicielek rodu - obok swej żyjącej matki i dwóch sióstr, Zofii Lubomirskiej i Anny Alojzy Chodkiewiczowej - stawała się przez to nie tylko dziedziczką wielkiej fortuny, lecz także spadkobierczynią książęcej legendy rodu ${ }^{9}$. Polepszenie prestiżu rodu nie było jednak głównym celem małżeństwa drugiego ordynata zamojskiego. Nie zamierzał on bowiem stać się kontynuatorem tradycji i legendy rodu kniaziów Ostrogskich, a bardziej liczył na przejęcie po nich spuścizny. Po pierwsze, w postaci majątków żony położonych głównie w Małopolsce, na Wołyniu i Ukrainie $^{10}$. Po drugie, poprzez przejęcie tamtejszej klienteli zwłaszcza po swych zmarłych szwagrach, Adamie Konstantym i Januszu Pawle Ostrogskich. Tomasz Zamoyski, który w południowo-wschodnich województwach Rzeczypospolitej posiadał już pewne majątki, a po ojcu odziedziczył wpływy polityczne, uważał bowiem ten rejon za naturalny kierunek swej ekonomiczno-politycznej ekspansji.

Nie sposób ustalić, na ile w domu rodzinnym nauczono przyszła ordynatowa zamojską całej społeczno-państwowej złożoności Rzeczypospolitej. Niewattpliwie jednak miała duże przywiazanie do własnego rodu

\footnotetext{
7 W 1604 r. o takie plany matrymonialne podejrzewał Jana Zamoyskiego nuncjusz papieski Claudio Rangoni (J. Dorobisz, W. Kaczorowski, Senat Rzeczypospolitej w relacji nuncjusza apostolskiego Claudio Rangoniego z 1604 r. [w:] Parlamentaryzm i prawodawstwo przez wieki: prace dedykowane prof. Stanisławowi Płazie w siedemdziesiata rocznice urodzin, red. J. Malec, W. Uruszczak, Kraków 1999, s. 41.

8 Na przełomie XVI i XVII w. do Ostrogskich należała trzecia część Wołynia oraz liczne majątki, głównie na Kijowszczyźnie, Podolu i w zachodniej Małopolsce, a także pomniejsze dobra w Wielkim Księstwie Litewskim (T. Kempa, Dzieje rodu Ostrogskich, Torun 2002, s. 158).

9 Claudio Rangoni oceniał, iż małżeństwo z przedstawicielką Ostrogskich będzie stanowiło dla Zamoyskich „wżenienie się” w możniejszy i bardziej starożytny ród magnacki (J. Dorobisz, W. Kaczorowski, op. cit., s. 41).

10 Tomasz Zamoyski poprzez małżeństwo z Katarzyna Ostrogską powiększył swój stan posiadania o około 10 miast i miasteczek, blisko 80 folwarków i 170 wsi, 4 zamki oraz kamienicę w Krakowie i dwory w Łucku. W 1621 r. dochód roczny z majątków Ostrogskich w sumie wynosił blisko 64260 zł (AGAD AZ, 715, Tabula Originalis, które dobra na trzy działy dostały, k. 1-2; J. Długosz, Podział latyfundium Ostrogskich w roku 1621, „Acta Universitatis Wratislaviensis" Historia XVI, 1969, nr 8, s. 5).
} 
i świadomość miejsca, jakie zajmowała w hierarchii społecznej. Zamoyska niejednokrotnie była pośrednikiem w staraniach dawnych klientów domu Ostrogskich związanych z zabiegami protekcyjnymi u jej męża. I tak np. w pierwszej połowie lat 20. XVII w. Tomasz Zamoyski w imieniu zwiazanego $z$ Ostrogskimi kasztelana rozpirskiego Jana Remiszowskiego zabiegał dla niego u dworu o wakujące starostwo stryjskie. O życzliwość względem próśb mężowskich i wpłynięcie na przychylność Zygmunta III listownie prosiła królowa Konstancję także sama Katarzyna ${ }^{11}$. Natomiast 1 grudnia 1622 r. kasztelan kijowski Hawryło Hoscki, powołując się na wieloletnia przyjaźń z Ostrogskimi oraz odwołując się do tradycji podtrzymywanych $z$ tym domem poprzez Katarzynę, liczył nie tylko na przedłużenie dzierżawy na przypadający Zamoyskim w wielkim dziale Koźlin, lecz także na kontynuację współpracy politycznej ${ }^{12}$. Najbardziej jednak spektakularny przykład odnosił się do Teofili Chmieleckiej, wdowy po znakomitym zagończyku Stefanie Chmieleckim, który pod koniec życia - dzięki wpływom Zamoyskiego - awansowany został na województwo kijowskie. Po śmierci męża Chmielecka zwracała się do Zamoyskiej o wsparcie w otrzymaniu przywileju dla osieroconych synów, Łukasza i Adama. Poprzez odpowiednie wpływy na lokalne sejmiki doprowadzono do podjęcia stosownych artykułów w tej kwestii. Te zainicjowane działania wspierał następnie na sejmie $1631 \mathrm{r}$. podkanclerzy Zamoyski. W czasie omawianego sejmu zebrana nań szlachta uznała zasługi Stefana Chmieleckiego i podjęła uchwałę o uwolnieniu od płacenia podymnego $z$ majętności należących do jego synów ${ }^{13}$.

W omawianym kontekście należy też wspomnieć o zaangażowaniu, jakim Zamoyska wykazywała się w stosunku do potomków swych wiernych klientów celem zapewnienia im opieki i właściwego wykształcenia. W zwiazku z posiadaniem przez Zamoyskich prywatnej Akademii były

\footnotetext{
11 BN BOZ, 1602, Tomasz Zamoyski do Jakuba Zadzika, Zamość, 26 X 1623 r., k. 233v; AGAD AZ 716, Tomasz Zamoyski do Zygmunta III, Zamość, 26 X 1623 r., k. 26 [kopia: BN BOZ, 1602, k. 233v-234]; BN BOZ, 1602, Katarzyna Zamoyska do Konstancji Habsburżanki, Zamość, 26 X 1623 r., k. 234-234v.

12 AGAD AZ 330, Hawryło Hoscki do Tomasza Zamoyskiego, Krupa, 1 XII 1622 r., k. 1-3.

13 Teofila Chmielecka do Katarzyny Zamoyskiej, Nowy Międzybórz, 24 III 1630 r., k. 1; Postanowienie Katarzyny Zamoyskiej na żadanie Teofili Chmieleckiej, [po marcu 1630 r.], k. 3-5. Więcej o Teofili z Chocimirskich i Stanisławie Chmieleckich zob. A.J. Rolle, Niewiasty kresowe: opowiadania historyczne, Warszawa 1883, s. 61-100; W. Dobrowolska, Chmielecki Stanisław [w:] Polski słownik biograficzny [PSB], t. 3, Kraków 1937, s. 318-320.
} 
ku temu szerokie możliwości ${ }^{14}$. Służba u możnego protektora otwierała ponadto możliwości kariery - jeśli nie urzędniczej czy państwowej, to przynajmniej dworskiej lub administracyjnej w dobrach magnackich. Zarzadzajac rozbudowanym prywatnym dworem kobiecym, magnatka spełniała również rolę patronki dla córek klientów jej męża. Szlachcianki miały tam zapewnione nie tylko utrzymanie, lecz także edukację, a w przyszłości możliwość korzystnego mariażu ${ }^{15}$. $Z$ tego też powodu wieloletni zarządca dóbr ukrainnych Jan Dzik po śmierci żony zwracał się z prośba o przyjęcie swych dwóch córek na usługi ordynatowej zamojskiej ${ }^{16}$.

Niewatpliwie przypadków odwołujących się do wieloletniej służby u Ostrogskich i nadziei na ich kontynuację u Zamoyskich za pośrednictwem Zamoyskiej było znacznie więcej ${ }^{17}$. Wszystkie świadczą o wysokiej pozycji magnatki i traktowaniu jej jako oczywistej, a co najważniejsze - atrakcyjnej politycznie kontynuatorki spuścizny rodu. Przykłady te stanowia ponadto dowód na udana polityczna współpracę małżeńska odnosząca się nie tylko do płynnego przechodzenia wieloletnich klientów pomiędzy rodami, lecz także do zorganizowanej i wielopokoleniowej strategii ich utrzymywania.

Niemal od pierwszych dni swego zamieszkania w Zamościu druga ordynatowa pośredniczyła w zbieraniu korespondencji oraz wiadomości ustnych, osobiście je spisując i odsyłając do miejsca, w którym aktualnie przebywał jej mąż. Bywały one pilne i miewały duże znaczenie z punktu widzenia działalności politycznej, którą zajmował się Zamoyski. Przykładem szczególnie istotnej korespondencji może być list Wojciecha Miaskowskiego do Zamoyskiej z 9 lutego 1624 r., w którym sługa Zamoyskich informował o zwycięstwie Stefana Chmieleckiego i Jana Dzika nad Tatarami oraz prosił o jak najszybsze przekazanie tej wieści mężowi. Katarzyna musiała się dobrze orientować w bieżących wydarzeniach,

\footnotetext{
14 Już po śmierci męża Katarzyna Zamoyska położyła kamień węgielny pod budowę nowego gmachu Akademii Zamojskiej oraz ufundowała katedrę teologii $z$ miejscem dla 12 kleryków (zob. J.K. Kochanowski, Dzieje Akademii Zamojskiej (1594-1784), Kraków 1899-1900, s. 99-102).

15 O roli dworu magnackiego zob. A. Pośpiech, W. Tygielski, Społeczna rola dworu magnackiego w XVII-XVIII w., „Przegląd Historyczny” 1978, t. 69, z. 2, s. 215-238; D. Makiłła, "Dwór" „ „patronat": dwa historyczno-socjologiczne pojęcia o historyczno-prawnym naświetleniu [w:] Patron i dwór..., s. 179-186.

16 AGAD AZ, 722, Jan Dzik do Tomasza Zamoyskiego, Szarogród, 14 II 1627 r., k. 35.

17 Ibidem, 357, Anna Ostrogska do Tomasza Zamoyskiego, Ostróg, 20 XII 1621 r., k. 28-29.
} 
albowiem sukces ten był ważny $z$ punktu widzenia kampanii sejmowej 1624 r., w która $-z$ pewnych politycznych względów w porozumieniu $z$ hetmanem polnym koronnym Stanisławem Koniecpolskim - szczególnie intensywnie zaangażował się wojewoda kijowski ${ }^{18}$.

W czasie nieobecności swego męża ordynatowa odpowiadała też za czuwanie i zbieranie informacji o zagrożeniu tatarskim i ich natychmiastowe przekazywanie. W korespondencji z lutego $1626 \mathrm{r}$. Zamoyska, powołując się na wytyczne męża i swój obowiązek, zapewniała go, iż odsyła każdy list przyniesiony jej z Ukrainy, bez względu na porę jego otrzymania. Ze względów bezpieczeństwa sama często otwierała nadsyłaną z pogranicza korespondencję adresowaną do magnata, najczęściej od Stefana Chmieleckiego ${ }^{19}$. $Z$ upływem lat Zamoyska $z$ coraz większą uwaga śledziła bieżące wydarzenia w kraju, okazując żywe zainteresowanie wszelkimi napływającymi informacjami, zwłaszcza odnoszacymi się do bezpieczeństwa na pograniczu południowo-wschodnim. W jednym $z$ listów do męża, napisanym po jesiennym najeździe w 1629 r., z charakterystycznym sobie temperamentem oceniła postawę wojska w następujący sposób:

Teraźniejsi nasi regimentarze wszystko, co czynia, to tylko dla prywat swoich. Wszyscy mężczyźni jako żółwiowie w skorupach siedzieli po wsiach, żaden się nie śmiał zza muru wychylić. Wiem, żem się urodziła do igły, nie do szabli, ale bym się nie frymarczyła swoim animuszem i sercem na ich błazeńskie serce. Szkoda, że się szlachta porodzili² ${ }^{20}$

Zamoyska była także godną reprezentantka interesów swego męża w czasie jego nieobecności w dobrach zamojskich i jeśli zachodziła konieczność, przyjmowała interesantów mężowskich, jak np. księdza arcy-

\footnotetext{
18 Ibidem, 955, Wojciech Miaskowski do Katarzyny Zamoyskiej, Jankowce, 9 II 1624 r., k. 1 .

19 Ibidem, 924, Katarzyna Zamoyska do Tomasza Zamoyskiego, Zamość, 26 II 1626 r., k. 26; Ibidem, 412, Katarzyna Zamoyska do Tomasza Zamoyskiego, Zamość, 7 III 1626 r., k. 30; Ibidem, Katarzyna Zamoyska do Tomasza Zamoyskiego, Zamość, 10 IX 1626 r., k. 32-35; Ibidem, Katarzyna Zamoyska do Tomasza Zamoyskiego, Zamość, 1 II 1628 r., k. 37, [druk: Ludzie i zdarzenia w barokowym Zamościu, wybór i oprac. H. Wiśniewska, Lublin 1996, s. 59-60]; Ibidem, Katarzyna Zamoyska do Tomasza Zamoyskiego, Zamość, 14 II 1628 r., k. 39; Ibidem, Katarzyna Zamoyska do Tomasza Zamoyskiego, Zamość, 21 II 1628, k. 41-42; Ibidem, Katarzyna Zamoyska do Tomasza Zamoyskiego, Zamość, 1 III 1628 r., k. 49; Ibidem, Katarzyna Zamoyska do Tomasza Zamoyskiego, Zamość, 6 X 1629 r., k. 55-65.

20 AGAD AZ, 412, Katarzyna Zamoyska do Tomasza Zamoyskiego, Zamość, 6 X 1629 r., k. 55-56.
} 
biskupa lwowskiego Jana Andrzeja Próchnickiego, który jesienią 1622 r. - według wytycznych drugiego ordynata - miał zostać stosownie przez nią ugoszczony w czasie nieobecności gospodarza. Pobyt duchownego na dworze zamojskim wypadł bardzo pomyślnie, skoro Zamoyska, składając relację $z$ pobytu zaprzyjaźnionego gościa, wspominała, iż starała się, aby $z$ największa ludzkościa był przyjęty, jakoż różowy, że dosyć kontent odjechat21 $\mathrm{Z}$ kolei jesienia $1621 \mathrm{r}$., w czasie trwającej kampanii chocimskiej, gościła w Zamościu udającego się na pospolite ruszenie do Lwowa Zygmunta III. Przebywajacy na pograniczu południowo-wschodnim Zamoyski szczegółowo instruował małżonkę, jak ma podejmować króla i jego świtę w Zamościu, a przy tym, jak zabiegać o ich względy ${ }^{22}$. Omawiana wizyta dworu królewskiego w majatkach Zamoyskich była bowiem doskonałą szansą na pozyskanie przywileju, o który małżonkowie zabiegali od dłuższego czasu. Jeszcze podczas przygotowań do kampanii chocimskiej Zamoyski zintensyfikował swe starania na dworze majace na celu uzyskanie pozwolenia królewskiego na zapisanie oprawy ślubnej Zamoyskiej na dobrach starostwa knyszyńskiego. Sam Zamoyski w czasie trwania kampanii chocimskiej eksponował na dworze fakt wsparcia finansowego udzielonego przez jego żonę $z$ pieniędzy pochodzacych $z$ sum posagowych. Nie wiemy, na ile działania wojewodziny kijowskiej wpłynęły na zgodę królewską na zapis omawianej oprawy (communicationem iuris), jednak na innych - zdecydowanie mniej dochodowych - dobrach królewskich w starostwie bełskim (wsiach bełskich). Jakkolwiek przywilej ten de facto oznaczał dożywotnie ich użytkowanie przez ordynatowa zamojska. Dokonano tego po wielu zabiegach dopiero w grudniu $1621 \mathrm{r}$. Małżonkowie nie byli jednak w pełni zadowoleni $z$ otrzymanego przywileju ${ }^{23}$.

\footnotetext{
${ }^{21}$ Ibidem, Katarzyna Zamoyska do Tomasza Zamoyskiego, Zamość, 19 X 1622 r., k. 11.

22 List $z$ wyrazami radości $z$ planowanego przyjazdu króla do Zamościa i $z$ analogiczna prośbą kierował także bezpośrednio do króla, piszac, iż ma nadzieję, że „to WKM nawiedzenie będzie początkiem i znakiem miłościwej WKM łaski i protectiey tak przeciwko gospodarzowi, jako i domowi”. BN BOZ, 1602, Tomasz Zamoyski do Zygmunta III, [Tarnopol, 22 IX 1621 r.], k. 69v; Ibidem, Tomasz Zamoyski do Jakuba Zadzika, Tarnopol, 22 IX 1621 r., k. 69v; AGAD AZ, 716, Tomasz Zamoyski do Katarzyny Zamoyskiej, Tarnopol, 24 IX 1621 r., k. 16-18; Ibidem, 924, Katarzyna Zamoyska do Tomasza Zamoyskiego, Zamość, 2 X 1621 r., k. 11.

23 AGAD AZ, 727, Jan Komorowski do Tomasza Zamoyskiego, Warszawa, 21 VII 1621 r., k. 108-113; BN BOZ, 1602, Tomasz Zamoyski do Jakuba Zadzika, Krupa, [4?] VIII 1621 r., k. 51v; Ibidem, Andrzej Lipski do Tomasza Zamoyski, Warszawa, 10 XII 1621 r., k. 88v-89; Ibidem, Tomasz Zamoyski do Andrzeja Lipskiego, br. m., br. d., k. 90v; Ibidem, Tomasz Zamoyski do Anny Ostrogskiej, Krzeszów, 29 XII 1621 r., k. 90-90v; Ibidem,
} 
Nie sposób w tym miejscu nie wspomnieć o pozycji, jaką na dworze Zygmunta III zajmowały otaczające go kobiety. Monarsze zarzucano zresztą, że przez całe panowanie słuchał „rad komornych” i ulegał wpływom kobiet. Wśród niewiast, których opinie na sprawy publiczne w latach 20. i 30. XVII w. brał on pod uwagę, wymienić można nie tylko siostrę króla Annę Wazównę i jego drugą żonę Konstancję Habsburżankę, lecz także przybyła wraz z pierwszą żoną Zygmunta III niezwykle wpływową dwórkę, pannę Urszulę Meyerin ${ }^{24}$. Zamoyski doskonale znał wartość najbliższego kobiecego otoczenia Zygmunta III, $z$ tego też powodu już w 1621 r. za pośrednictwem królewny Anny i ochmistrzyni dworu panny Urszuli rozpoczał zabiegi u królowej Konstancji we wspomnianej sprawie nadania zapisu oprawy ślubnej Zamoyskiej.

Należy przyznać, iż pierwsze próby wkupienia się w łaski dworu królewskiego nie były zbyt udane, niebawem jednak wojewodzie kijowskiemu udało się je polepszyć,m.in. przez pośrednictwo żony.

Zamoyska nawiazywała kontakty $z$ dworem królewskim stopniowo, najpierw towarzysząc mężowi w wyjazdach, czy to na konwokacje, czy też na sejmy ${ }^{25}$. Obecność małżonków przy królu mogła bardzo ułatwić karierę polityczna. O wpływie i znaczeniu kobiet na warszawskim dworze wojewoda kijowski wiedział od osób mu życzliwych i dobrze zorientowanych $\mathrm{w}$ realiach dworskich. Osoby te doradzały mu zdecydowane zabiegi, najlepiej osobiste, o przychylność rodziny królewskiej i jej najbliższego otoczenia.

Analiza korespondencji Zamoyskiej świadczy o jej wzrastającym zaangażowaniu w karierę polityczna męża. $Z$ okresu następującego po sejmie $1624 \mathrm{r}$. pochodzi jedno $z$ najwcześniejszych znanych świadectw odnoszacych się do działalności wojewodziny kijowskiej w omawianej sferze publicznej. Napotykamy je w jej liście skierowanym do Urszuli Meyerin, list ten był bowiem zauważalną cezurą w stosunkach magnatki z zapleczem dworskim. Jeszcze w czasie pobytu Zamoyskich w Warszawie w 1624 r. Katarzynie udało się nawiązać bliższe kontakty z najbardziej

Ekspeditia do dworu przez Pana Komorowskiego do króla, królowej i królewny od Tomasza Zamoyskiego i Katarzyny z Ostrogskich Zamoyskiej, Krzeszów, 23 I 1622 r., k. 96v-98.

${ }^{24}$ O Annie Wazównie, Konstancji Habsburżance i Urszuli Meyerin zob. W. Leitsch, Das Leben am Hof König Sigismunds III. von Polen, Wien-Kraków 2009, Bd. 2, s. 1074-1110, Bd. 3, s. 1447-1568, 1848-1922.

25 AGAD AZ, 412, Katarzyna Zamoyska do Tomasza Zamoyskiego, Lublin, 24 III 1628 r., k. 51; Ibidem, Katarzyna Zamoyska do Tomasza Zamoyskiego, Zamość, 20 II 1629, k. 53. 
prominentnymi osobami z otoczenia królewskiego. Jak czytamy w liście, Zamoyska, korzystając $z$ okazji posyłania przez jej męża korespondencji do Warszawy, także uznała, iż jest to doskonała sposobność przypomnienia o sobie u ochmistrzyni dworu królewskiego i wystosowania prośby o stały kontakt, czy to listowny, czy też werbalny, przekazywany za pośrednictwem służby lub przyjaciół jej męża. Zamoyska dopominała się o protekcję jej osoby przed królową w następujący sposób:

Upominając się u WM tej obiecanej ludzkości, żeś mnie zapominać nie miała, y często przypominać iako uniżoną sługę Królowej Jej Mci Pani Naszej Miłościwej, o której zdrowiu y powodzeniu proszę abyć WM za occasiami, jeśli pismem w zabawach swych tamecznych nie możesz, namniey, kiedy się sługa albo przyjaciel, który Jego Mci Pana Małżonka mego trafi ustnie oznaimowała. [Na zakończenie zaś prosiła pannę Urszulę, aby] będąc przy boku Królowej Jej Mci przytomna pokazywała mi drogę do służb Jej Królewskiej Mci y sama w swej chęci nieodmiennie mię chowała ${ }^{26}$.

List wydaje się tym bardziej interesujący, że jako jedyny z zachowanego korpusu korespondencyjnego Zamoyskiej nie był pisany ręka magnat$\mathrm{ki}^{27}$. Po charakterze pisma i jego stylistyce językowej $\mathrm{z}$ dużym prawdopodobieństwem możemy stwierdzić, iż stał za nim sam Zamoyski. Przytoczony przykład najlepiej świadczy o doskonałej orientacji Zamoyskich w pozycji kobiet oraz ich wpływie na świat polityki i ówczesnej praktyki podejmowania decyzji królewskich. Należy przy tym podkreślić, że interwencja przedsiębiorczej magnatki musiała mieć poważny charakter, pozwalający jej mężowi na pozaformalne działanie polityczne na dworze królewskim, w sytuacji gdy tradycyjna protekcja wśród ministrów i sekretarzy nie była dość skuteczna. A przypomnijmy, że lata 1621-1624 były okresem, gdy Zamoyski podejrzewany był o działania opozycyjne w stosunku do polityki królewskiej.

\footnotetext{
26 AGAD AZ, 954, Katarzyna Zamoyska do Urszuli Meyerin, Zamość, 26 III 1624 r., k. 3-4.

27 Katarzyna Zamoyska przy pisaniu swych listów nie korzystała $z$ pomocy sekretarza i niemal cała jej zachowana korespondencja (poza kilkoma wyjatkami) była przez nia własnoręcznie pisana. Podobnie jak jej matka Anna $z$ Kostków Ostrogska czy też teściowa Barbara z Tarnowskich Zamoyska nie stosowała także dużych liter i znaków interpunkcyjnych. Zgodnie $z$ ustaleniami Haliny Wiśniewskiej jej język w pisowni i mowie zdradza, iż uczyła ją osoba starsza, znająca bardzo dobrze zasady językowe obowiazujace poprzednie pokolenie, być może była to któraś z benedyktynek jarosławskich (H. Wiśniewska, op. cit., s. 169-172).
} 
Na poczatku 1626 r. Zamoyski przystapił do jeszcze bardziej zdecydowanego ocieplania własnego wizerunku na dworze królewskim. Zbliżenie do króla było dla wojewody kijowskiego niezbędne do osiagnięcia zamierzonego celu w postaci buławy mniejszej po - jak planowano - uprzednim awansie na buławę większą dotychczasowego hetmana polnego Stanisława Koniecpolskiego. Magnat - zgodnie $z$ ponawianymi zalecaniami życzliwych mu osób - oprócz większego zaangażowania w działalność wojskową równolegle szczególnie intensywnie zabiegał o względy królowej Konstancji i co bardziej wpływowych dworzan ${ }^{28}$. W działaniach tych wspierała go także żona przesyłająca na jego polecenie na dwór królewski liczne drobne upominki. By zaskarbić sobie w ten sposób odrobinę łaski króla, królowej i ministrów, na ogół każdego obdarowywano z osobna. Wkrótce posyłanie upolowanych zwierzat i ryb pochodzacych ze stawów folwarcznych należacych do Zamoyskich stało się zresztą ich stałym zwyczajem ${ }^{29}$. Zamoyski ostatecznie buławy nie otrzymał, pomimo że jesienia 1626 r. brał niezwykle czynny udział przy boku króla w kampanii wojennej w Prusach Królewskich. Swoje niezadowolenie zamanifestował opuszczeniem teatru działań wojennych i niespodziewanym wyjazdem $\mathrm{w}$ czasie trwania sejmu w Toruniu. Wzbudziło to duże zaniepokojenie Zygmunta III i jego doradców oraz podejrzenia o działalność opozycyjna. $\mathrm{W}$ tak niezręcznej sytuacji ordynatowa zamojska podjęła się niełatwego zadania wytłumaczenia działań męża przed królem ${ }^{30}$. Mediacja okazała się na tyle skuteczna, iż już pod koniec1626 r. dochodziły do Zamościa informacje, że Zygmunt III bardzo przychylnie odnosił się do pomysłu audiencji Zamoyskich u króla, co też prawdopodobnie miało miejsce na początku $1627 \mathrm{r}^{31}$

${ }_{28}$ Osoby życzliwe na dworze doradzały Tomaszowi Zamoyskiemu, aby ten w czasie swego pobytu na sejmie „comodował” się królowej i wraz ze swym odjazdem z sejmu „dworskich wszystkich dobrze konfirmowanych zostawił”. Ponadto wojewoda kijowski powinien zaskarbić sobie życzliwość sekretarza wielkiego Mikołaja Szyszkowskiego oraz „chwytać” się i współpracować z królewiczem Władysławem (AGAD AZ, 741, Wojciech Serebryski do Tomasza Zamoyskiego, Bodzencin, 4 III 1626 r., k. 55-58).

${ }^{29}$ Na przykład wtedy, gdy Zamoyska wspominała mężowi o wykonaniu zleconego przez niego polecenia przesłania na dwór królewski pstragów i łań ofiarowanych królowi oraz przekazanego przy tej okazji listu od niej do ochmistrzyni dworu królewskiego (Ibidem, 412, Katarzyna Zamoyska do Tomasza Zamoyskiego, Zamość, 14 II 1628 r., k. 39).

30 Ibidem, 10, Informacja pochodząca $z$ opisu niezachowanego listu: Urszula Meyerin do Katarzyny Zamoyskiej, Ujazdów, 17 XII 1626 r., k. 14, poz. 4, [dawna sygnatura: AGAD $\mathrm{AZ}, 424]$.

31 Ibidem, 351, Maciej Łubieński do Tomasza Zamoyskiego, Warszawa, br. d. [XII? 1626 r.], k. 38-39. 
Z czasem pozycja Zamoyskiej na dworze królewskim ulegała wzmocnieniu. O jej rosnącym znaczeniu dowiadujemy się $z$ informacji, jakie $z$ niego otrzymywała. 19 lipca $1631 \mathrm{r}$. podczas pobytu Zamoyskiego na leczeniu w czeskich Cieplicach informowała męża o okolicznościach śmierci królowej. Nadzwyczaj szczegółowe wiadomości posiadała bowiem nie tylko od ochmistrzyni dworu, lecz także od obecnej tam dobrze poinformowanej kuchmistrzowej ${ }^{32}$. O rozległości kontaktów $z$ dworem świadczą jej częste wzmianki odnoszące się do niezachowanej niestety korespondencji wysyłanej do króla, królowej, ich dzieci oraz pań dworskich ${ }^{33}$. $\mathrm{Z}$ czasem magnatka nawiąała na tyle przyjacielskie, niemalże rodzinne stosunki z dworem królewskim, że już bez pośrednictwa męża zabiegała o przywileje dla swych bliskich, jak to np. miało miejsce w 1633 r., gdy za pośrednictwem Urszuli Mayerin upraszała Władysława IV o opisanie oprawy ślubnej nieznanej jej z nazwiska krewnej na pewnych majątkach w Krzeszowie ${ }^{34}$.

Doskonale znając wartość bezpośrednich kontaktów $z$ rodzina królewska, Zamoyska stosunkowo wcześnie zadbała o podtrzymywanie tych relacji przez swe potomstwo. Do stałego kanonu dbania o jak najlepsze stosunki na dworze królewskim należało obdarowywanie rodziny królewskiej i dworzan kosztownymi upominkami. W dopisku do listu z 17 października 1634 r. do męża Zamoyska wspominała o wykonanym przez lutnika szkiełku, które - wraz z ułożona przez ich jedenastoletnia córkę Gryzeldę fraszką i słodyczami z marcepanu - miało zostać ofiarowane cztery lata starszej królewnie Annie Katarzynie Konstancji. Z listu tego dowiadujemy się także o radach udzielanych jej przez chorażynę nurską, która częstokroć upominała Zamoyska, aby ta „kazała robić pilnie tę służbę królewnie jego mości". Zamoyska w swych działaniach podporządkowywała się jednak głównie woli męża, a szukając jego ak-

\footnotetext{
${ }_{32}$ W liście tym Katarzyna Zamoyska wspominała także o bezpośredniej korespondencji do Zygmunta III, w której dopytywała się o zdrowie królowej Konstancji (Ibidem, 412, Katarzyna Zamoyska do Tomasza Zamoyskiego, Zamość, 19 VII 1631 r., k. 59-61 [druk: S. Gołębiewski, Pamiętnik o Tomaszu Zamoyskim, kanclerzu w. kor, „Biblioteka Warszawska" 1853 , t. 52, s. 427-428; Ludzie i zdarzenia..., s. 62-63].

33 W niezachowanym liście zaledwie czternastoletnia królewna Anna Katarzyna Konstancja Wazówna ubolewała nad złym stanem zdrowia Tomasza Zamoyskiego, życzyła jego polepszenia i dziękowała za dowody stałej przyjaźni (AGAD AZ, 10, Anna Katarzyna Konstancja Wazówna do Katarzyny Zamoyskiej, Warszawa, 21 VII 1633 r., k. 7, poz. 2 [dawna sygnatura: AGAD AZ, 413]).

34 Ibidem, 954, Katarzyna Zamoyska do Urszuli Meyerin, Kraków, 13 IV 1633 r., k. 1.
} 
ceptacji, gotowa była nawet poprosić Gryzeldę o przygotowanie odpowiedniego listu do królewny ${ }^{35}$. Bez wattpienia tego typu korespondencyjne kontakty magnatek oprócz ich osobistej bytności na dworze królewskim należy traktować jako przykład politycznej aktywności kobiet wspierajacych działania swych małżonków.

Pozostałe znane przypadki świadcza jedynie pośrednio o aktywności Zamoyskiej w sferze publicznej. I tak np. w styczniu 1639 r. Franciszek Czarnkowski, nazywając siebie krewnym i wieloletnim sługa, oznajmił Zamoyskiej o chęci i gotowości do dalszej służby zarówno jego, jak i jego bliskich ${ }^{36}$. Natomiast w połowie 1627 r. marszałkowa nadworna koronna Anna Opalińska zwracała się do ordynatowej z prośbą o wstawiennictwo u wojewody kijowskiego w sprawie jej krewnego Ulińskiego, $\mathrm{w}$ innym liście zaś gratulowała narodzin syna ${ }^{37}$. Gratulacje $z$ tego samego powodu składał również zaprzyjaźniony $z$ domem Zamoyskich biskup krakowski Marcin Szyszkowski ${ }^{38}$. Jeszcze bardziej serdecznie przedstawiają się kontakty Zamoyskiej z Anną z Radzimińskich Leszczyńska, żoną wojewody bełskiego Rafała Leszczyńskiego ${ }^{39}$. Nic w tym dziwnego, skoro obaj magnaci przez lata byli niezwykle bliskimi przyjaciółmi. Utrzymywana przez Zamoyska korespondencja służyła zatem podtrzymywaniu układów rodzinnych i towarzyskich nie tylko $z$ ówczesna elitą senatorsko-dygnitarska, lecz także $z$ licznymi klientami i sąsiadami. Trzeba zauważyć, że przesyłanie gratulacji $z$ okazji narodzin potomków, składanie powinszowań ślubnych czy też kondolencji z powodu śmierci członka rodziny było częścią obyczaju szlacheckiego. Idealnym pretekstem do przypomnienia się adresatowi były corocznie obchodzone święta. Szczególnie częstym powodem do składania życzeń świątecznych był okres noworoczny. W tym względzie korespondencja magnatki w zasadzie niewiele się różniła od korespondencji prowadzonej przez jej męża. I w jednym, i w drugim przypadku mamy do czynienia ze składaniem zapewnień o życzliwości i przywiązaniu. Wydaje się jednak, iż w przypadku

\footnotetext{
${ }_{35}$ Ibidem, Katarzyna Zamoyska do Tomasza Zamoyskiego, Krzeszów, 17 X 1634 r., k. 59-60.

36 Franciszek Czarnkowski do Katarzyny Zamoyskiej, Rzemień, 29 I 1639 r., k. 29.

37 AGAD AZ, 460, Anna Opalińska do Katarzyny Zamoyskiej, Łaki, 20 IV 1627 r., k. 1; Ibidem, 424, Anna Opalińska do Katarzyny Zamoyskiej, Łąki, 6 VI 1627 r., k. 11.

38 AGAD AZ, 424, Marcin Szyszkowski do Katarzyny Zamoyskiej, Klęka, 17 IV 1627 r., k. 9.

39 Ibidem, Anna Leszczyńska do Katarzyny Zamoyskiej, Włodawa, 4 XII 1626 r., k. 5; AGAD AZ, 951, Anna Leszczyńska do Katarzyny Zamoyskiej, Włodawa, 27 XII 1626 r., k. 1; Ibidem, 356, Anna Opalińska do Tomasza Zamoyskiego, Łaki, 5 VI 1627 r., k. 10.
} 
drugiej ordynatowej zamojskiej te częste kontakty powodowały, że łatwiej było zaskarbić sobie sympatię wpływowego męża i wyraźnie się nasiliły po otrzymaniu przez niego urzędu ministerialnego.

Na przełomie lat 20. i 30. XVII w., a zatem już po otrzymaniu przez Zamoyskiego pieczęci mniejszej, Katarzyna podjęła pierwsze samodzielne próby protegowania swych kandydatów na urzędy. Mianowicie krewny Jerzy Zasławski prosił ordynatową zamojską o wstawiennictwo $\mathrm{u}$ podkanclerzego koronnego $\mathrm{w}$ otrzymaniu pewnego starostwa ${ }^{40}$, rok później zaś podkomorzy bełski Andrzej Kretkowski prosił „o przyczynę” u jej męża w celu przekazania urzędu podkomorzego brzeskiego swemu bratu Jerzemu ${ }^{41}$. Zamoyska wykazywała się ponadto czujnościa, a nawet pewną zawziętościa w zabiegach o urzędy i godności dla swego męża, krewnych i przyjaciół. Dowód poświadczający aktywność polityczną pani na Zamościu w omawianym zakresie można znaleźć w liście $z$ pierwszej połowy 1628 r., w którym Zamoyska donosiła Tomaszowi o zasłyszanych od jej przebywającego we Lwowie informatora pogłoskach o śmierci wojewody ruskiego Jana Daniłowicza, który w rzeczywistości zmarł blisko trzy miesiace później. Jakkolwiek świadoma niesprawdzonych plotek o jego śmierci Zamoyska była jednak przekonana, iż nie wadziłoby wtręt prośby swej uczynić, bo pewnie z tej choroby nie wylezie, choćby go teraz minęła. Nadmieniała przy tym, że krewni spieszą ze spustem stawów i szybkim spieniężeniem ryb w starostwach należących do magnata ${ }^{42}$. Zwłaszcza te ostatnie posiadane przez Daniłowicza starostwa burskie, bełskie, korsuńskie bądź czechryńskie szczególnie mogły zainteresować Zamoyskiego. Przytoczone przeze mnie przykłady moga świadczyć nie tylko o miejscu ordynatowej zamojskiej w systemie protekcyjnym, lecz także dowodzą, że tak poważna pozycję kobiet w świecie polityki współcześni uważali za rzecz normalną.

Katarzyna bardzo wspierała Zamoyskiego nie tylko w jego karierze politycznej, lecz także wojskowej. W tym ostatnim względzie przejawiało się to na ogół $\mathrm{w}$ działaniach informacyjnych i aprowizacyjnych

\footnotetext{
40 Ibidem, 993, Jerzy Zasławski do Katarzyny Zamoyskiej, Zasław, 2 III 1630 r., k. 1. Natomiast 6 czerwca 1627 r. marszałkowa nadworna koronna Anna Opalińska polecała swego krewnego nieznanego $z$ imienia Ulińskiego, prosząc Katarzynę Zamoyską o wstawiennictwo za nim (o „przyczynę swa”) u jej wpływowego męża (Ibidem, 424, Anna Opalińska do Katarzyny Zamoyskiej, Łąki, 6 VI 1627 r., k. 11).

41 Ibidem, 499, Andrzej Kretkowski do Katarzyny Zamoyskiej, Hodecz, 4 XI 1631 r., k. 1.

42 Ibidem, 412, Katarzyna Zamoyska do Tomasza Zamoyskiego, Zamość, 1 III 1628 r., k. 49.
} 
(niejednokrotnie organizowała - zgodnie $z$ wytycznymi męża - wysyłanie żywności i wszelkich niezbędnych aparatów wojennych) niż stricte wojskowych. O częściowej bezradności magnatki w zarządzaniu i egzekwowaniu porządku w prywatnych oddziałach wojskowych moga świadczyć problemy, z jakimi borykała się w czasie nieobecności męża w Zamościu. Przypadek taki miał miejsce w lutym 1628 r., kiedy to Zamoyski wyjechał na rokowania ze Szwedami do Prus Królewskich. W ślad za wojewoda kijowskim miał wyruszyć krewny Zamoyskich, wojewodzic bracławski Stanisław Potocki ${ }^{43}$. Nieposłuszny krewny nie chciał jednak się podporządkować wcześniejszym ustaleniom. Zamiast doprowadzić powierzone mu oddziały piechoty do obozu magnata wolał przebywać w Zamościu lub jego okolicach (na ogół w Borku), trwoniąc wzięte za służbę pieniądze i spędzając całe dni przy szklanicy. Wojewodzina kijowska, powodowana interesem jej męża i w obawie o bezpieczeństwo miasta, usiłowała - na ogół za pośrednictwem sług wojskowych - zmusić wojewodzica bracławskiego do natychmiastowego wyjazdu do Prus Królewskich. Nie wiemy, jak się skończyła omawiana sprawa, jednak w związku $z$ faktem, iż w późniejszej korespondencji Zamoyskiej do męża nie znajdujemy już wzmianek na ten temat, możemy domniemywać o pozytywnym rozwiązaniu problemu niesubordynowanego powinowatego ${ }^{44}$.

Kolejny ślad zwiazany $z$ aktywnością Zamoyskiej w zakresie działań wojskowych znajdujemy w liście, jaki wystosowała do swego męża w połowie $1631 \mathrm{r}$. Zamoyski przebywał wówczas na leczeniu „w czeskich wodach". Wobec grożącego najazdu tatarskiego i przygotowaniach do odparcia zagrożenia pisała w następujacy sposób:

Nas strasza Tatary i uniwersały hetmańskie przychodza do żołnierzów żeby się kupili (...). Pan hetman jeno po 50 koni pod choragwiami pozostawiał wm mego miłościwego pana choragiew. Nie chcac tak wchodzicz do wojska kuso, we 100 koni chca wniść do obozu. Rozumieja to o łasce wm, że tą ich chęcią i miłością towarzyską nie pogardzisz.

\footnotetext{
43 Stanisław Potocki h. Pilawa (1607-1647) był synem wojewody bracławskiego Jakuba i Jadwigi z Tarnowskich. Jadwiga była młodsza siostra Barbary z Tarnowskich Zamoyskiej, matki drugiego ordynata Tomasza Zamoyskiego (W. Majewski, Stanisław Potocki [w:] PSB, t. 28, Wrocław 1984-1985, s. 151-53).

44 AGAD AZ, 924, Katarzyna Zamoyska do Tomasza Zamoyskiego, Zamość, 8 II 1628 r., k. 42-43; Ibidem, 412, Katarzyna Zamoyska do Tomasza Zamoyskiego, Zamość, 14 II 1628 r., k. 39; Ibidem, Katarzyna Zamoyska do Tomasza Zamoyskiego, Zamość, 21 II 1628 r., k. 41-42.
} 
Podkanclerzyna koronna, nie chcac samodzielnie decydować o sprawach prowadzonego zaciagu, odsyłała żołnierzy do wojskowych pełnomocników magnata:

Jeździli z Bełza do mnie, ale ja [w to - M.K.] co mi nie należy, wdawać się nie chciała. Prosili żebym ich asekurowała, że im ta ćwierć nie zginie, bo oni dla sławy dobrodzieja naszego, niewidzenia $z$ tak kusa choragwią. Alem ja ich do sług odsyłała, żeby nie zaniechali z rycerskimi odprawami i temi zabawami nie obraził mi jego mości głowy ani mnie niewieście, zleciła regimentu tego o to ich według informacyjnej od wm podanej odprawiono ${ }^{45}$.

Zgodnie $z$ ustaleniami badaczy położenie społeczne wdów było zdecydowanie bardziej samodzielne niż to miało miejsce w przypadku panny czy mężatki, które na ogół przebywały pod opieką ojca, bliskich krewnych lub męża. Odnosiło się to nie tylko do statusu prawnego i majątkowego, lecz także aktywności w sferze publicznej. Życie mężatki miało się bowiem skupiać głównie wokół problemów domu i rodziny, a jej reprezentantem w kwestiach prawno-majątkowych był mąż. Dopiero po jego śmierci wdowa mogła śmielej reprezentować swój interes w przestrzeni publicznej. Nie bez wpływu na jej pozycję pozostawał oczywiście stopień zamożności i przejętych po zmarłym mężu kontaktów politycznych ${ }^{46}$. Podobnie było w przypadku Zamoyskiej, która - jak się wydaje - największą aktywność w sferze publicznej przejawiała w okresie wdowieństwa, czyli już od początku 1638 r. Okres ten trwał niespełna pięć lat, stanowi on jednak dowód na to, iż kanclerzyna doskonale umiała samodzielnie przypilnować swych spraw.

Pomimo wyznaczenia przez Zamoyskiego licznych prawnych opiekunów ordynacji, majątku i jego nieletnich potomków szybko pojawily się pierwsze problemy sądowe ${ }^{47}$. Nie mogąc jednak osobiście prowadzić intere-

\footnotetext{
45 AGAD AZ, 412, Katarzyna Zamoyska do Tomasza Zamoyskiego, Zamość, 19 VII 1631 r., k. 59-61 [druk: S. Gołębiewski, op. cit., s. 62-63 (list błędnie odczytany)].

${ }_{46}$ Zob. M. Bogucka, Białogłowa $w$ dawnej Polsce..., op. cit.; J. Kuchta, Pozycja majatkowa wdów z rodów szlacheckich w XVII-XVIII wieku [w:] Rodzina i gospodarstwo domowe na ziemiach polskich $w X V-X X$ wieku: struktury demograficzne, społeczne i gospodarcze, red. C. Kuklo, Warszawa 2008, s. 261-270.

47 Prawnymi opiekunami małoletniego Jana Zamoyskiego zostali: hetman Stanisław Koniecpolski, kanclerz litewski Albrycht Stanisław Radziwiłł, prymas Maciej Łubieński, wojewoda bełski Jakub Sobieski i biskup krakowski Jakub Zadzik (J. Kuś, Powitanie Jana Zamoyskiego „Sobiepana” $w$ Zamościu po powrocie $z$ peregrynacji zagranicznych w 1646 r., „Archiwariusz Zamojski” 2010, t. 9, s. 7).
} 
sów prawnych, wdowa $z$ podziwu godna skutecznościa zabiegała o protekcję u dawnych przyjaciół zmarłego małżonka. Jej bierność w tym względzie mogła zreszta stwarzać poważne problemy prawno-majątkowe. $Z$ korespondencji, jaka w 1641 r. Zamoyska wystosowała do Stanisława Koniecpolskiego, dowiadujemy się, że dopraszała się ona u hetmana wielkiego koronnego popierania jej interesów na Trybunale Koronnym. Koniecpolski zaangażował się w sądowe problemy Zamoyskiej z wyjątkową gorliwościa, wystosowując aż 15 listów do duchownych i świeckich deputatów trybunalskich ${ }^{48}$. Jednego $z$ nich - Stanisława Witowskiego - szczególnie intensywnie nakłaniał do wpłynięcia na innych członków składu sędziowskiego, zapewniając o dozgonnej wdzięczności wdowy po zmarłym kanclerzu ${ }^{49}$.

Zaangażowanie Katarzyny z Ostrogskich Zamoyskiej w okresie wdowieństwa ukierunkowane było w głównej mierze na kwestie majątkowe i gospodarcze, po śmierci męża przejęła bowiem zarzą nad Ordynacją Zamojska. Ponadto kanclerzyna koronna miała prawo dożywotniego użytkowania dwóch starostw - sokalskiego i knyszyńskiego - należących dawniej do jej męża. W okresie niepełnoletności jej syna Jana, późniejszego trzeciego ordynata zamojskiego, odpowiedzialna była także za zarząd nad starostwem kałuskim. Do najważniejszych zagadnień poruszanych w listach w latach 1638-1642 należa sprawy zwiazane $z$ zarządzaniem rozległym latyfundium. Oprócz kwestii błahych, jak np. prośba Adama Lipskiego o interwencję $\mathrm{w}$ sprawę worania się $\mathrm{w}$ jego grunt przez poddanych ordynatowej ${ }^{50}$, Zamoyska zmuszona była do rozwiazywania bardziej złożonych problemów zwłaszcza odnoszących się do dóbr szarogrodzkich. Bacznie śledziła sprawy dla siebie ważne i kontrolowała poczynania swych ludzi, skomplikowana sytuacja na pograniczu i oddalenie od Zamościa nie ułatwiały jej jednak zadania. Już 13 stycznia 1639 r. Władysław IV zalecał Zamoyskiej, aby zleciła swym ukrainnym dozorcom zatrzymywanie wszystkich osób przemieszczających się przez jej pograniczne dobra bez paszportów królewskich. Król wyczulał szczególnie na posłańców przenoszących listy pomiędzy Moskwą a Turcją oraz informujących obydwu

\footnotetext{
48 Byli to kolejno: kanonik chełmski Świerski, wojewoda malborski Samuel Konarski, sędzia ziemski halicki Adam Łychowski, łowczy wołyński Rafał Małachowski, choraży zatorski Krzysztof Żydowski, sędzia ziemski kaliski Maciej Jaskólski, pisarz ziemski Łucki, podczaszy bełski Janusz Prusinowski, dziekan przemyski, podkomorzy łucki, podsędek bracławski Daniel Hulewicz, kantor przemyski oraz podsędek łucki (AGAD AZ, 446, Stanisław Koniecpolski do Stanisława Witowskiego i innych, Brody, 24 V 1641 r.).

49 Ibidem, Stanisław Koniecpolski do Stanisława Witowskiego, Brody, 24 V 1641 r.

50 AGAD AZ, 952, Adam Lipski do Katarzyny Zamoyskiej, Adamów, 8 VIII 1639 r., k. 1.
} 
sąsiadów o sytuacji w Rzeczypospolitej. Z kontekstu wynika, iż zainteresowaniem sąsiadów cieszyły się zwłaszcza informacje o położeniu wyznawców religii greckiej na Ukrainie ${ }^{51}$.

Ukraińskie majątki przysparzały pani na Zamościu w okresie wdowieństwa nadzwyczaj dużo problemów. W jej korespondencji można odnaleźć liczne dowody poświadczające o zatargach granicznych jej raszkowskich poddanych z poddanymi hospodara mołdawskiego. Szczególnie niebezpieczny dla zachowania spokoju na Ukrainie był najazd na przygraniczne tereny mołdawskie, do jakiego - ponoć w odwecie za poczynione przez Mołdawian w majętnościach Zamoyskiej szkody - dopuścił się podstarości raszkowski, prowadząc ze sobą z Raszkowa dwustu ludzi. W wyniku najazdu poddani hospodara zostali zabici lub porwani, a ich majatki zagrabione. Samego perkułaba sorockiego uwięziono, a wysłanego przez hospodara na mediację dwornika omal nie porwano. Wzburzony Bazyli Lupu, powołując się na wieloletnią przyjaźń z Zamoyskim, pisał wprost, że takie zachowanie poddanych magnatki stawało się już kwestia bezpieczeństwa i zachowania pokoju pomiędzy Rzeczpospolita a Mołdawią. Hospodar mołdawski użalał się ponadto, iż namiestnicy pograniczni na wszelkie insolentie rozpasali sie tak dalece, że o środek już trudno do pohamowania rozbiegłym kotom ${ }^{52}$. W mediacje pomiędzy zwaśnione strony włączył się Stanisław Koniecpolski - zobligowany przez króla do utrzymania bezpieczeństwa na granicy polsko-mołdawskiej, osobiście zainteresowany był jak najszybszym rozwiąaniem konfliktu ${ }^{53}$.

Pomimo swych problemów ordynatowa zamojska nie traciła również uwagi związanej $z$ działalnościa sticte polityczna. To właśnie wtedy stanęła na czele domu i stronnictwa. Interesowała się nie tylko sytuacja polityczną w Europie Zachodniej czy życiem dworu królewskiego (o tych kwestiach szczegółowo informował ja sekretarz królewski Wojciech Serebryski) ${ }^{54}$, lecz także rozdawnictwem urzędów. Do tej ostatniej kwestii

\footnotetext{
51 Ibidem, 413, Władysław IV do Katarzyny Zamoyskiej, Zambrów, 13 I 1639 r., k. 3.

52 Ibidem, Bazyli Lupu do Katarzyny Zamoyskiej, Jassy, 26 VI 1639 r., k. 10-11.

53 AGAD AZ, 416, Stanisław Koniecpolski do Katarzyny Zamoyskiej, Krystynopol, 21 VI 1639 r., k. 10; Ibidem, 939, Jan Dzik do Katarzyny Zamoyskiej, Stanisławów, 1 VII 1639 r., k. 6-7.

54 Kanonik krakowski Wojciech Serebryski informował Katarzynę Zamoyska np. o przebiegu zagranicznej podróży królewicza Jana Kazimierza i jego aresztowaniu w Paryżu oraz o planach Władysława IV zwiąanych $z$ wyjazdem do cieplic w Baden i wymaganej w zwiazku z opuszczeniem przez króla Rzeczypospolitej zgody sejmu (Ibidem, 970, Wojciech Serebryski do Katarzyny Zamoyskiej, Kraków, 25 VII 1628 r., k. 1-2).
} 
odnosi się jej list do kanclerza wielkiego koronnego Piotra Gembickiego, w którym kanclerzyna protegowała Franciszka Bądzyńskiego na urząd podkomorzego chełmskiego ${ }^{55}$. Intersująca jest argumentacja, jakiej użyła. Wdowa podkreślała, iż nie tyle popiera swego kandydata przez wzgląd na jego ojca, który był przed laty domowym przyjacielem magnatki, ile z powodu faktu, że będzie on pożyteczny królowi i miejscowej szlachcie chełmskiej. Protekcja kanclerzyny nie przyniosła pożądanego skutku, ponieważ urząd podkomorzego chełmskiego otrzymał ostatecznie mający znaczne wpływy Mikołaj Daniłowicz. Zamoyska podjęła się zreszta niełatwego zadania, objęcie najwyższego w hierarchii ziemskiej urzędu sądowego po ojcu należało bowiem do precedensów, a jego szanse były tym bardziej znikome, albowiem młody Bądzyński nie pełnił jak dotąd żadnych funkcji56. Nie ulega przy tym watpliwości, iż Zamoyska była kobietą interesująca się życiem politycznym, a co najmniej pilnie śledząca zmiany na urzędach. List jej jest także świadectwem niezłej orientacji w zasadach ruchu personalnego zwiazanego $z$ lokalnymi wakansami.

Na koniec należałoby jeszcze wspomnieć o postawie religijnej Katarzyny z Ostrogskich Zamoyskiej względem swoich poddanych, sług i klientów innej wiary. W przeciwieństwie do swej siostry Anny Alojzy z Ostrogskich Chodkiewiczowej, która cechowała się obsesyjną wręcz niechęcią do niekatolików, Zamoyska szanowała zarówno religię matki, jak i swego prawosławnego ojca. Posiadanie majątków na Wołyniu oraz pełnienie najwyższego świeckiego urzędu na Ukrainie zmuszało Zamoyskiego do wykazywania względnie tolerancyjnych postaw. Oczywiście Zamoyscy $z$ wyjątkowym uprzywilejowaniem traktowali religię rzymskokatolicka, przeznaczając znaczne sumy na różnorodne fundacje sakralne, równocześnie musieli jednak być protektorami wobec innych wyznań. Wielowyznaniowość tego skomplikowanego regionu Rzeczypospolitej, w których posiadali swe wpływy, wymagała bowiem od nich sprawiedliwego traktowania wszystkich swoich poddanych, co też miało

\footnotetext{
55 Pisząc o nim w następujących słowach: „Za ześciem $z$ tego świata nieboszczka pana Bądzyńskiego podkomorzego chełmskiego, wakuje temi czasy urzą ten podkomorstwa, na czym iż wielce należy, aby to mieśce człowiekiem godnym, bogobojnym y prawa umiejętnym osadzone było, zalecam WM memu Mciwemu Panu syna nieboszczka, pana Franciszka Bądzyńskiego, człowieka w tey tu ziemi chełmskiey wziętego y wszystkim Ich Mciom PP Obywatelom dobrze zachowałego. Za którym wielce się przyczyniając uniżenie proszę, abyś go WM moy Mciwy Pan przed inszemi u Je Kr Mci promować na ten urząd raczeł" (RS, Extranea IX Polen, 112, Katarzyna Zamoyska do Piotra Gembickiego, Zamość, 25 IV 1642 r.). 56 E. Opaliński, op. cit., s. 242.
} 
miejsce. Dopiero kilka miesięcy przed śmiercią nastąpiła dość znaczna zmiana w postępowaniu Zamoyskiego. Magnat wydał wówczas uniwersały wymierzone przeciwko arianom w Szczebrzeszynie i prawosławnym na Wołyniu ${ }^{57}$. Po jego śmierci Katarzyna $z$ wyjątkowym zacietrzewieniem kontynuowała nietolerancyjną politykę wyznaniową męża względem swych poddanych. Szczególna gorliwość wykazywała w nawracaniu prawosławnych na unię. Jedno $z$ najwcześniejszych świadectw odnoszących się do działalności magnatki w omawianej sferze można napotkać w liście skierowanym do niej przez unickiego metropolitę kijowskiego Rafała Korsaka. Dziękował on magnatce za starania czynione na rzecz nawracania na unię jej poddanych $z$ szarogrodzko-kraśnieńskich majętności. Ich wynik przerósł oczekiwania nawet samego duchownego ${ }^{58}$. $Z$ kolei nowo mianowany na protopopię satyjowską Jędrzej Reczyński, dziękując protektorce za otrzymana prebendę, zapewniał o swym zaangażowaniu $\mathrm{w}$ wykonywanie poleconego mu zadania zwiąanego $\mathrm{z}$ nawracaniem na unię duchownych prawosławnych i jej poddanych $z$ okolicznych majętności ${ }^{59}$. Natomiast namiestnik monastyru żydyczyńskiego Izajasz Pierecki wstawiał się do Zamoyskiej za duchownym prześladowanym przez władykę łuckiego i ostrogskiego Atanazego Puzynę za przystapienie do unii. Prosił przy tym dla niego o wakujace probostwo w Kotowie ${ }^{60}$. Trafnie to ujał unicki biskup przemyski Atanazy Krupecki, gdy zwracając się do księżnej Zamoyskiej z prośbą o wyznaczenie placu i drewna na zbudowanie cerkwi unickiej w Krzeszowie, nazwał ja dwojakiego narodu pania ${ }^{61}$.

W dobie staropolskiej życie kobiety ograniczać się miało do sfery prywatnej, wymiar publiczny pozostawiając mężczyznom. W propagowanych wzorcach podkreślano, że miało być one podporządkowane woli mę-

\footnotetext{
57 O fundacjach sakralnych Tomasza i Katarzyny Zamoyskich zob. A.L. Płatek, op. cit., s. 37. Odnośnie do polityki wyznaniowej, a także szarogrodzko-kraśnieńskiej protopopi na Podolu zob. L. Jarmiński, Tomasz Zamoyski wobec spraw publicznych i wyznaniowych, „Odrodzenie i Reformacja w Polsce” 1980, t. 25, s. 128-137; A. Gil, I. Skoczylas, Kościoty wschodnie $w$ państwie polsko-litewskim $w$ procesie przemian $i$ adaptacji: metropolia kijowska $w$ latach 1458-1795, Lublin-Lwów 2014, s. 158-163; I. Skochilyas, Dvolikiy Yanus: Shargorods'ka protopopiya na Podilli v pershiy tretini XVII st., „Visnik L'vivs'kogo Universitetu. Seriya Istorichna” 2002, vip. 37, ch. 1, s. 161-182.

58 AGAD AZ, 424, Rafał Korsak do Katarzyny Zamoyskiej, Żydyczyn, 22 VII 1639 r., k. 53.

59 Ibidem, Jędrzej Reczyński do Katarzyny Zamoyskiej, Satyjów, 7 VI 1639 r., k. 45.

60 AGAD AZ, 964, Izajasz Pierecki do Katarzyny Zamoyskiej, Żydyczyn, 3 VI 1939 r., k. 1-2.

61 Ibidem, 424, Atanazy Krupecki do Katarzyny Zamoyskiej, Przemyśl, 4 VII 1639 r., k. 51.
} 
żów. Analiza materiału korespondencyjnego Zamoyskiej, oprócz tematów zwiazanych $z$ problemami rodzinnymi i codziennościa, świadczy o tym, iż należała ona do kobiet w jakimś stopniu dażących do wpływu na życie publiczne i na pewno - podobnie jak jej niepospolita matka wojewodzina wołyńska Anna z Kostków Ostrogska - nie była przeciętną osobowością ${ }^{62}$. Zaangażowanie drugiej ordynatowej zamojskiej w życie publiczne należy przy tym podzielić na dwa etapy: trwajaccy niespełna osiemnaście lat okres małżeństwa oraz prawie pięcioletni czas wdowieństwa.

W małżeństwie zaangażowanie Zamoyskiej w działalność polityczną inspirował jej mąż wojewoda kijowski Zamoyski, który w pierwszej połowie lat 20. XVII w. był w niełasce na dworze królewskim. To on zgodnie $z$ radami zaufanych dworzan królewskich - dyktował jej pierwsze listy do kobiet $z$ najbliższego otoczenia króla. Na tej podstawie trudno przypuszczać, by Zamoyska bez wiedzy i aprobaty męża sama chwytała za pióro. I chociaż listy do członków rodziny królewskiej pisała już jej teściowa Barbara $z$ Tarnowskich Zamoyska, to jednak korespondencja Zamoyskiej $z$ czasem stała się bardziej poufna i mniej sformalizowana. Poruszano w niej tematy nie tylko zwiazane $z$ aktualna polityka, lecz także odnoszace się do problemów życia codziennego, jak np. zdrowie rodziny królewskiej. Korespondencja ta zakończona była zazwyczaj czułymi pozdrowieniami i zapewnieniami o ofiarowanych służbach. Często do korespondencji dołączano prezenty w postaci słodkości czy drobnych podarunków. Kontakty $z$ dworem królewskim zaliczyć zatem należy do kategorii stałych, a nie okazjonalnych korespondentów magnatki. Tradycja utrzymywania więzi z rodziną królewską podtrzymywana była ponadto poprzez młodsze pokolenie Zamoyskich.

Po śmierci Zamoyskiego w styczniu 1638 r. Katarzyna doskonale radziła sobie $z$ samodzielną korespondencja, o czym świadcza zachowane listy do Władysława IV i jego żony odnoszace się do spraw majątkowych. W latach 40. XVII w. ordynatowa zamojska protegowała nawet swych kandydatów na urzędy. Nie robiła tego osobiście, a o jej interesy, także te na sejmikach, walczyli dawni przyjaciele polityczni jej zmarłego męża. Dokonywała tego ponadto, korespondując $z$ wpływowymi osobistościami sceny

62 Nie wiemy jednak, w jakim zakresie na jej charakter wpłynęła energiczna i przedsiębiorcza księżna Anna z Kostków Ostrogska (zob. K. Gottfried, Anna Ostrogska, wojewodzina wołyńska: zarys biograficzny na tle dziejów Jarosławia, Jarosław 1939; K. Kieferling, Jarosław w czasach Anny Ostrogskiej. Szkice do portretu miasta i jego właścicielki (15941635), Przemyśl 2008). 
politycznej. Bez watpienia tak wysoka pozycja Zamoyskiej wynikała przede wszystkim $z$ jej samodzielności majątkowej w okresie wdowieństwa ${ }^{63}$.

Analiza źródeł o charakterze epistolograficznym obejmujacych krag korespondentów Katarzyny z Ostrogskich Zamoyskiej pozwala stwierdzić, iż w znacznym stopniu interesowała się ona wydarzeniami politycznymi i przebiegiem działań wojennych. Co więcej - starała się nawet realnie uczestniczyć w życiu publicznym, zakulisowo ingerując w lokalne sądownictwo i administrację oraz wpływając na rozdawnictwo dóbr i urzędów. Prowadziła przy tym bogate życie towarzyskie, czy to asystując mężowi w podróżach sejmowych, czy też - podczas jego nieobecności - przyjmując na swym dworze szczególnie blisko zwiąanych z Zamoyskim stronników politycznych. Charakterystyczne było też zjawisko utrzymywania przez nią osobnego kobiecego kręgu korespondencyjnego. Obejmował on niewiasty przebywające w najbliższym otoczeniu dwóch pierwszych królów $z$ dynastii Wazów oraz żon ówczesnych najważniejszych senatorów i dygnitarzy Rzeczypospolitej. Omawiana korespondencja pozwala ponadto wysnuwać wnioski bardziej ogólne o tym, że kobiety pierwszej połowy XVII w. nie były jedynie pasywnymi odbiorcami i przekaźnikami wiadomości publicznych, ale za pomocą dostępnych im środków w pewnym zakresie usiłowały oddziaływać na kształtowanie ówczesnej polityki. Zgodzić się zatem wypada $z$ teza postawioną przez Edwarda Opalińskiego, który stwierdził, iż na aktywizacje polityczna kobiet $w$ Rzeczpospolitej Obojga Narodów wpływ królowych Francuzek mógt mieć jedynie ograniczony, a nie jak do tej pory sadzono, zasadniczy charakter ${ }^{64}$.

63 Tomasz Zamoyski w swym testamencie nadał jej pełne prawa do dożywotniego zarzadzania majatkiem (Testament Tomasza Zamoyskiego (1633, 1637) [w:] Testamenty Jana, Tomasza i Jana „Sobiepana” Zamoyskich, oprac. W. Kaczorowski, Opole 2007, s. 66-70). 64 E. Opaliński, op. cit., s. 241. 


\section{Bibliografia}

\section{Źródła archiwalne}

Archiwum Główne Akt Dawnych, Archiwum Zamoyskich [AGAD AZ], 10, 412-424, 460, 924, 931-997.

\section{Źródła publikowane}

Intercyza ślubna z Katarzyna księżniczka Ostrogska między księżna Imcia Anna z Szemberka Ostrogska wojewodzina wotyńska uczyniona a Imcia Panem Tomaszem Zamoyskim wojewoda kijowskim, oprac. Marta Kupczewska, „Białostockie Teki Historyczne” 2013, t. 11, s. 287-293, ISSN 1425-1930.

Ludzie i zdarzenia $w$ barokowym Zamościu, wybór i oprac. Halina Wiśniewska, Lublin : Wydawnictwo Uniwersytetu Marii Curie-Skłodowskiej, 1996, ISBN 83-227-0899-8.

Pamiętnik o Tomaszu Zamoyskim, kanclerzu w. kor, oprac. Seweryn Gołębiewski, „Biblioteka Warszawska” 1853, t. 52, s. 197-229, 397-432.

Testamenty Jana, Tomasza i Jana „Sobiepana” Zamoyskich, oprac. Włodzimierz Kaczorowski, Opole : Wydawnictwo Uniwersytetu Opolskiego, 2007, ISBN 978-83-7395-265-2.

\section{Opracowania}

Bogucka Maria, Białogłowa $w$ dawnej Polsce: kobieta $w$ społeczeństwie polskim XVI-XVIII wieku na tle porównawczym, Warszawa : „Trio”, 1998, ISBN 83-85660-78-X.

Bogucka Maria, Kobieta $w$ społeczeństwie polskim XVI-XVII wieku [w:] Pamiętnik XV Powszechnego Zjazdu Historyków Polskich, t. 2: Przemiany społeczne a model rodziny, red. Anna Żarnowska, Gdańsk-Toruń : Wydawnictwo Adam Marszałek, 1995, s. 3-15.

Charewiczowa Łucja, Kobieta $w$ dawnej Polsce: do okresu rozbiorów, Poznań : Poznańskie Towarzystwo Przyjaciół Nauk, 2002, ISBN 83-7063-334-X. Codzienne kłopoty, wielkie interesa i podwójna elekcja: korespondencja radziwiłłowskich urzędników z księżna Anna z Sanguszków Radziwiłłowa i jej synem Michałem Kazimierzem z 1733/1734 roku, wyd. Jerzy Dygdała, Warszawa : Wydawnictwo DiG, 2013, ISBN 978-83-7181-777-9. 
Długosz Jan, Podział latyfundium Ostrogskich w roku 1621, „Acta Universitatis Wratislaviensis", Historia XVI, 1969, nr 8, s. 3-15, ISSN 0524-4498.

Dobrowolska Wanda, Chmielecki Stanisław [w:] Polski słownik biograficzny, t. 3, [red. Władysław Konopczyński et al.], Kraków : Polska Akademia Umiejętności, 1937, s. 318-320.

Dorobisz Janusz, Kaczorowski Włodzimierz, Senat Rzeczypospolitej w relacji nuncjusza apostolskiego Claudio Rangoniego z 1604 r. [w:] Parlamentaryzm i prawodawstwo przez wieki: prace dedykowane prof. Stanisławowi Płazie $w$ siedemdziesiata rocznice urodzin, red. Jerzy Malec, Wacław Uruszczak, Kraków : Wydawnictwo Uniwersytetu Jagiellońskiego, 1999, s. 31-43.

Drogi kobiet do polityki (na przestrzeni XVIII-XXI wieku), red. Teresa Kulak, Małgorzata Dajnowicz, Wrocław : Wydawnictwo Chronicon, 2016, ISBN 978-83-946166-2-5.

Gil Andrzej, Skoczylas Ihor, Kościoly wschodnie w państwie polsko-litewskim w procesie przemian i adaptacji: metropolia kijowska w latach 1458-1795, Lublin-Lwów : Instytut Europy Środkowo-Wschodniej, 2014, ISBN 97883-60695-77-7.

Gottfried Kazimierz, Anna Ostrogska, wojewodzina wolyńska: zarys biograficzny na tle dziejów Jarosławia, Jarosław : Muzeum Miejskie, 1939.

Górski Karol, Matka Mortęska, Kraków : Znak, 1971.

Jakuboszczak Agnieszka, Sarmacka dama: Barbara Sanguszkowa (17181791) i jej salon towarzyski, Poznań : Wydawnictwo Poznańskie, 2008, ISBN 978-83-7177-487-4.

Jarmiński Leszek, Tomasz Zamoyski wobec spraw publicznych $i$ wyznaniowych, „Odrodzenie i Reformacja w Polsce” 1980, t. 25, s. 113-138, ISSN 0029-8514.

Karkucińska Wanda, Anna z Sanguszków Radziwiłłowa (1676-1746): działalność gospodarcza i mecenat, Warszawa : Wydawnictwo Naukowe Semper, 2000, ISBN 83-86951-79-6.

Kempa Tomasz, Dzieje rodu Ostrogskich, Torun : Wydawnictwo Adam Marszałek, 2002, ISBN 83-7174-971-6.

Kieferling Krystyna, Jarosław w czasach Anny Ostrogskiej: szkice do portretu miasta i jego właścicielki (1594-1635), Przemyśl : Archiwum Państwowe, 2008, ISBN 978-83-88172-27-4. 
Kobiece kręgi korespondencyjne w XVII-XIX wieku, red. Bożena Popiołek, Urszula Kicińska, Agnieszka Słaby, Warszawa : Wydawnictwo DiG, 2016, ISBN 978-83-7181-977-3.

Kochanowski Jan Karol, Dzieje Akademii Zamojskiej (1594-1784), Kraków : [s.n.], 1899-1900.

Kuchta Joanna, Pozycja majatkowa wdów z rodów szlacheckich w XVIIXVIII wieku [w:] Rodzina i gospodarstwo domowe na ziemiach polskich w XV-XX wieku: struktury demograficzne, spoleczne i gospodarcze, red. Cezary Kuklo, Warszawa: Wydawnictwo DiG, 2008, s. 261-270.

Kuchowicz Zbigniew, Postawa wobec kobiety $w$ kulturze szlacheckiej polskiego baroku [w:] Kobieta w kulturze i spoleczeństwie, red. Barbara Jedynak, Lublin : Wydawnictwo Uniwersytetu Marii Curie-Skłodowskiej, 1990, s. 7-50.

Kuchowicz Zbigniew, Żywoty niepospolitych kobiet polskiego baroku, Łódź : Wydawnictwo Towarzystwa Krzewienia Kultury Świeckiej, 1989, ISBN 83-85030-13-1.

Kuś J., Powitanie Jana Zamoyskiego „Sobiepana” w Zamościu po powrocie $z$ peregrynacji zagranicznych $w 1646$ r., „Archiwariusz Zamojski” 2010, t. 9, s. 7-14, ISSN 2083-3091.

Leitsch Walter, Das Leben am Hof König Sigismunds III. von Polen, Bd. 2-3, Wien : Verlag der Österreichischen Akademie der Wissenschaften; Kraków : Polska Akademia Umiejętności, 2009, ISBN 978-83-7676-0131.

Majewski Wiesław, Stanisław Potocki [w:] Polski słownik biograficzny, t. 28, [red. Władysław Konopczyński, et al.], Wrocław : Zakład Narodowy im. Ossolińskich, 1984-1985, s. 151-153.

Makiłła Dariusz, „Dwór” i „patronat”. Dwa historyczno-socjologiczne pojęcia o historyczno-prawnym naświetleniu [w:] Patron i dwór: magnateria Rzeczypospolitej w XVI-XVIII wieku, red. Ewa Dubas-Urwanowicz, Jerzy Urwanowicz, Warszawa : Wydawnictwo DiG, 2006, s. 179-186.

Opaliński Edward, Aktywność kobiet w życiu publicznym $w$ czasach pierwszych Wazów [w:] „Per mulierem...”: kobieta $w$ dawnej Polsce - $w$ średniowieczu i $w$ dobie staropolskiej, red. Katarzyna Justyniarska-Chojak, Sylwia Konarska-Zimnicka, Warszawa : Wydawnictwo DiG, 2010, s. 233-248. 
Partyka Joanna, „Żona wyćwiczona”: kobieta piszaca w kulturze XVI i XVII wieku, Warszawa: Wydawnictwo Instytutu Badań Literackich PAN, 2004, ISBN 83-89348-22-5.

Płatek Agnieszka Lidia, Kochajaca żona - Katarzyna z Ostrogskich Zamoyska (1600-1642), „Zamojski Kwartalnik Kulturalny” 2013, nr 2, s. 34-38, ISSN 0239-8710.

Popiołek Bożena, Dobrodziejki i klienci: $z$ dziejów patronatu kobiecego w czasach saskich [w:] Patron i dwór: magnateria Rzeczypospolitej w XVI-XVIII wieku, red. Ewa Dubas-Urwanowicz, Jerzy Urwanowicz, Warszawa : Wydawnictwo DiG, 2006, s. 385-395.

Popiołek Bożena, Kobiecy świat w czasach Augusta II: studium z mentalności kobiecej czasów saskich, Kraków : Wydawnictwo Naukowe Akademii Pedagogicznej, 2003, ISBN 83-7271-188-7.

Popiołek Bożena, Królowa bez korony: studium z życia i działalności Elżbiety z Lubomirskich Sieniawskiej - ok. 1669-1729, Kraków : Wydawnictwo Naukowe Wyższej Szkoły Pedagogicznej, 1996, ISBN 83-86841-13-3.

Pośpiech Andrzej, Tygielski Wojciech, Społeczna rola dworu magnackiego w XVII-XVIII w., „Przegląd Historyczny” 1978, t. 69, z. 2, s. 215-237, ISSN 0033-2186.

Rafałowiczówna Jadwiga, A $z$ Warszawy nowiny te...: listy do Elżbiety Sieniawskiej z lat 1710-1720, oprac. Bożena Popiołek, Kraków : Wydawnictwo Naukowe Akademii Pedagogicznej, 2000, ISBN 83-7271-025-2.

Rolle Antoni Józef, Niewiasty kresowe: opowiadania historyczne, Warszawa : Gebethner i Wolff, 1883.

Seredyka Jan, Księżniczka i chudopachołek: Zofia z Radziwiłłów Drohostajska, Opole : Wydawnictwo Uniwersytetu Opolskiego, 1995, ISBN 8385678-44-1.

Skochilyas Igor, Dvolikiy Yanus: Shargorods'ka protopopiya na Podilliv pershiy tretini XVII st., „Visnik L'vivs'kogo Universitetu. Seriya Istorichna” 2002, vip. 37, ch. 1, s. 161-182, ISSN 0206-565.

Słaby Agnieszka, Dwór Elżbiety z Lubomirskich Sieniawskiej jako przykład patronatu kobiecego $w$ czasach saskich, Kraków : Wydawnictwo Libron, 2014, ISBN 978-83-64275-35-7.

Targosz Karolina, Sawantki w Polsce XVII w.: aspiracje intelektualne kobiet ze środowisk dworskich, Warszawa : „Retro-Art”, 1997, ISBN 83906742-1-1. 
Tyszka Paweł, W cieniu wielkiego kanclerza: Barbara z Tarnowskich Zamoyska, Warszawa: Wydawnictwo Neriton, 2015, ISBN 978-83-7543-376-0.

Wiśniewska Halina, Kultura języka Katarzyny Zamoyskiej $w$ świetle jej listów do męża, „Pamiętnik Literacki” 1990, t. 81, z. 4, s. 167-182, ISSN 0031-0514.

Witusik Adam Andrzej, O Zamoyskich, Zamościu i Akademii Zamojskiej, Lublin : Wydawnictwo Lubelskie, 1978.

Wyrobisz Andrzej, Kobiety w spoleczeństwie staropolskim: wzorce a model rodziny [w:] Pamiętnik XV Powszechnego Zjazdu Historyków Polskich, t. 2: Przemiany społeczne a model rodziny, red. Anna Żarnowska, GdańskTorun : Wydawnictwo Adam Marszałek, 1995, s. 16-28.

Wyrobisz Andrzej, Staropolskie wzory rodziny i kobiety - żony i matki, „Przegląd Historyczny" 1992, z. 3, s. 405-421, ISSN 0033-2186.

Zagórska Sylwia, Halszka z Ostroga: między faktami a mitami, Warszawa: Wydawnictwo DiG, 2006, ISBN 978-83-7181-419-8. 